\title{
楕円軌道上において群衛星の相対位置関係を維持する軌道設計法*1 The Orbital Synthesis for Maintaining the Formation Geometry in Elliptic Orbits
}

\author{
夏 目耕一 $* 2$. 佐 伯 孝 尚 $* 2$. 川口淳一郎 $* 3$ \\ Koichi Natsume, Takanao SAIKI and Jun'ichiro KAwAGUChI
}

Key Words : Formation Flight, Elliptic Orbit, Geometry Keeping

\begin{abstract}
For formation flight missions, it is often required for the satellite members to maintain a favorable relative position. There have been many researches about the navigation, guidance and control on the formation flight. But many of those researches are on the active control, that is, the control with delta-V mostly in circular orbits. Although the passive geometry maintenance without fuel should be emphasized for the mission life, there is little such research about it. Furthermore, the most researches for formation flying have dealt with the circular orbit using the Hill's equation. This paper discusses the design method for maintaining the formation geometry without performing orbit control on the elliptic orbits.
\end{abstract}

記 号 の 説 明

軌道要素

$\begin{array}{lll}a & : & \text { 長半径 } \\ e & : & \text { 離心率 } \\ i & : & \text { 軌道傾斜角 } \\ \Omega & : & \text { 昇交点経度 } \\ \omega & : & \text { 近地点引数 } \\ f & : & \text { 真近点離角 } \\ M & : & \text { 平均近点離角 } \\ u & : & \text { 離心近点離角 } \\ t_{0} & : & \text { 近点通過時刻 } \\ t & : & \text { 時刻 } \\ n & : & \text { 平均運動 } \\ p & : & \text { 半直弦 }\end{array}$

スカラー, ベクトル

$\mu \quad$ : 地心重力定数

$R_{e}:$ 地球半径 $(\approx 6378[\mathrm{~km}])$

$r \quad$ ： 相対位置ベクトル

1. は じめに

多くのフォーメーションフライトミッションでは衛星群 は適切な相対位置関係を維持することが求められる。 その ため, 現在衛星フォーメーションフライトに関する相対航 法, 誘導制御に関する研究が盛んに行われている. しかし ながら, それらの研究の多くは, 複数衛星をある幾何的な 配置に誘導, 維持するための然料消費を前提とした積極的

\footnotetext{
*1 C 2004 日本航空宇宙学会

平成 15 年 7 月 14 日原稿受理

*2 東京大学大学院工学系研究科航空宇宙工学専攻

*3 宇宙航空研究開発機構宇宙科学研究本部
}

な制御に関する研究である. 本来は燃料消費を抑制しミッ ション寿命の長期化を図るという意味でも, 制御をするこ となく衛星間の相対位置を受動的に，または自動的に維持 したいという要求があるのだが，そのような研究はかなり 稀である。また，過去のフォーメーションフライト関連の 論文は慣性系での運動を扱ったものや，軌道運動を考慮し たとしても円軌道周りの線形化された簡単な Hill の方程式 を扱ったものがほとんどである。しかし，実際の衛星ミッ ションは円軌道のみとは限らず, むしろ楕円軌道が必要と されるものも多い，そこで本研究は，楕円軌道上で軌道制 御を積極的に行うことなく衛星群の相対位置関係を維持す る軌道の設計法について扱う。具体的には

1) 衛星間距離を一定にする軌道の設計

2) 相似な 2 次元幾何形状を維持する軌道の設計 を行った. 軌道設計の際の解を解析的に得ることができ, こ のことは本研究の一つの特徵となっている．楕円上フォー メーションフライトでは一般に衛星間の相対位置の変化が 大きく, 直感的には相対位置関係の維持は困難であると考 えられるが, 軌道設計の結果は意外にも相対位置関係をよ く保つものであり有意であることが分かった.

\section{2. 相対位置ベクトル表現}

2.1 基準衛星近傍の相対運動の線形近似式 ${ }^{1)}$ 長半径 $a$, 離心率 $e$ の基準衛星を考える. 地球中心を原点として, 基 準衛星の動径方向を $X_{r}$ 軸, $X_{r}$ 軸と直交し基準軌道の進行 方向が正となるように軌道面内に $Y_{r}$ 軸, 軌道面外方向に 右手系を構成するように $Z_{r}$ 軸をとった回転座標系を定義 すると, 基準衛星の位置ベクトル $\boldsymbol{r}_{r e f}$ は 


$$
\begin{aligned}
& \boldsymbol{r}_{r e f}=\left(r_{r e f}, 0,0\right)^{\mathrm{T}} \\
& r_{r e f}=\frac{a\left(1-e^{2}\right)}{1+e \cos f}
\end{aligned}
$$

と表される.

今, 基準衛星が $\left(a, e, i=0, \Omega=0, \omega=0, t_{0}\right)$ の軌道上 にあるとき，この軌道面を基準面として

$$
\left(a^{\prime}, e^{\prime}, i^{\prime}, \Omega^{\prime}, \omega^{\prime}, t_{0}^{\prime}\right)
$$

の軌道要素を持つ衛星の運動を考える. 昇交点経度は基準 衛星の近点方向を基準として測る. 衛星が基準衛星の近傍 に存在するためには,

1) 軌道形状がほぼ同じであること

2) 軌道上での位置がほぼ同じであること

が必要である。基準軌道が楕円軌道である場合にはこれら の条件は,

$$
\begin{aligned}
& |\delta a|<<1,|\delta e|<<1,|\delta i|<<1 \\
& |\delta \omega|<<1,\left|\delta t_{0}\right|<<1
\end{aligned}
$$

であるとして，

$$
\begin{aligned}
& a^{\prime}=a+\delta a, e^{\prime}=e+\delta e, i^{\prime}=\delta i \\
& \Omega^{\prime}+\omega^{\prime}=2 \pi \times k+\delta \omega \quad(k: \text { 整数, } \delta \omega<<1)
\end{aligned}
$$

および，

$$
t_{0}^{\prime}=t_{0}+\delta t_{0}
$$

と書くことができる.

基準軌道が円軌道である場合にも，軌道形状がほぼ等し い条件は

$$
a^{\prime}=a+\delta a, e^{\prime}=e+\delta e, i^{\prime}=\delta i
$$

となる，基準軌道が円軌道である場合には，基準軌道に近 地点という概念がないため，軌道上での位置がほぼ同じで あるという条件に関しては工夫が必要となる。本稿では, 基 準衛星の近地点 (存在しないが) を春分点方向と仮定し, 真 近点離角 $f$ の基準も春分点方向とする. このとき, 衛星の 真近点離角 $f^{\prime}$ の基準は衛星の近地点であるから, 軌道上で の両者の位置がほぼ同じである条件は

$$
\left|f^{\prime}-\left(f-\left(\Omega^{\prime}+\omega^{\prime}\right)\right)\right|<<1
$$

とすることができる.よって，両者の間の軌道上での微小 な位相差を

$$
n \delta t_{0}=f^{\prime}-\left(f-\left(\Omega^{\prime}+\omega^{\prime}\right)\right), \quad\left|\delta t_{0}\right|<<1
$$

で表すことにする， $n$ は基準衛星の平均運動である.

改めて $\Omega^{\prime}=\Omega, \omega^{\prime}=\omega$ とおくと, 前述の回転座標系に おける衛星の位置ベクトル $\boldsymbol{r}_{s / c}$ は

$$
\boldsymbol{r}_{s / c}=\boldsymbol{R}_{z}(-f) \boldsymbol{R}_{z}(\Omega) \boldsymbol{R}_{x}(\delta i) \boldsymbol{R}_{z}\left(\omega+f^{\prime}\right)\left(\begin{array}{c}
r^{\prime} \\
0 \\
0
\end{array}\right)
$$

となる.ここで $\boldsymbol{R}_{x}, \boldsymbol{R}_{z}$ はそれぞれ $x$ 軸， $z$ 軸周りの回転 変換を表す. $r^{\prime}, f^{\prime}$ は衛星の動径および真近点離角である. 基準軌道が円軌道の場合には，前述のように，基準軌道と 衛星の真近点離角の基準が異なるため,

$$
\Omega+\omega=\varpi
$$

として

$$
\begin{aligned}
& r^{\prime}=a+\left.\frac{\partial r_{r e f}}{\partial a}\right|_{f-\varpi} \delta a+\left.\frac{\partial r_{r e f}}{\partial e}\right|_{f-\varpi} \delta e \\
& f^{\prime}=f-\varpi+\left.\frac{\partial f}{\partial a}\right|_{f-\varpi} \delta a+\left.\frac{\partial f}{\partial e}\right|_{f-\varpi} \delta e+n \delta t_{0}
\end{aligned}
$$

と表すことができる．また，基準軌道が楕円軌道である場 合には

$$
\begin{aligned}
r^{\prime}= & r_{r e f}+\left.\frac{\partial r_{r e f}}{\partial a}\right|_{f} \delta a+\left.\frac{\partial r_{r e f}}{\partial e}\right|_{f} \delta e \\
& +\left.\frac{1}{n} \frac{\partial r_{r e f}}{\partial t_{0}}\right|_{f} n \delta t_{0} \\
f^{\prime}= & f+\left.\frac{\partial f}{\partial a}\right|_{f} \delta a+\left.\frac{\partial f}{\partial e}\right|_{f} \delta e+\left.\frac{1}{n} \frac{\partial f}{\partial t_{0}}\right|_{f} n \delta t_{0}
\end{aligned}
$$

とできる. 式 (12)〜式 (15) の各係数は以下のようにして 求められる.

基礎式として

$$
\begin{aligned}
& n\left(t-t_{0}\right)=E-e \sin E, \quad n=\sqrt{\mu / a^{3}} \\
& r_{r e f}=a(1-e \cos E) \\
& \cos E=\frac{e+\cos f}{1+e \cos f} \\
& \sin E=\frac{\sqrt{1-e^{2}} \sin f}{1+e \cos f} \\
& \cos f=\frac{\cos E-e}{1-e \cos E} \\
& \sin f=\frac{\sqrt{1-e^{2}} \sin E}{1-e \cos E}
\end{aligned}
$$

の関係を用いる. 式 $(16)$ の両辺を $a, e, t_{0}$ で偏微分し, 式 (16)～式 (21) の関係式を用いて整理することで以下の式を 得る.

$$
\begin{aligned}
& \frac{\partial E}{\partial a}=-\frac{3}{2} \frac{n\left(t-t_{0}\right)}{r_{\text {ref }}} \\
& \frac{\partial E}{\partial e}=\frac{1}{\sqrt{1-e^{2}}} \sin f \\
& \frac{\partial E}{\partial t_{0}}=-\frac{n(1+e \cos f)}{1-e^{2}}
\end{aligned}
$$

式 (17) の両辺を $a, e, t_{0}$ で偏微分し, 式 $(22)$ 式 $(24)$ を 代入することで, 


$$
\begin{aligned}
& \frac{\partial r_{r e f}}{\partial a}=\frac{r_{r e f}}{a}-\frac{3}{2} \frac{n\left(t-t_{0}\right) e \sin f}{\sqrt{1-e^{2}}} \\
& \frac{\partial r_{r e f}}{\partial e}=-a \cos f \\
& \frac{\partial r_{r e f}}{\partial t_{0}}=-\sqrt{\frac{\mu}{p}} e \sin f
\end{aligned}
$$

を得る. 同様にして, 式 $(21)$ の両辺を $a, e, t_{0}$ で偏微分 し，式 (22)〜式 (24) を代入することで,

$$
\begin{aligned}
\frac{\partial f}{\partial a} & =-\frac{3}{2} \frac{n\left(t-t_{0}\right) a \sqrt{1-e^{2}}}{r_{r e f}^{2}} \\
\frac{\partial f}{\partial e} & =\frac{(2+e \cos f) \sin f}{1-e^{2}} \\
\frac{\partial f}{\partial t_{0}} & =-\sqrt{\frac{\mu}{p^{3}}}(1+e \cos f)^{2}
\end{aligned}
$$

を得ることができる.

式 (25)〜式 (30) を式 (12)〜式 (15) に代入し $r^{\prime} ， f^{\prime}$ を得 た後, 式 (10) に代入することで衛星の位置ベクトルを得る ことができ，更に

$$
\boldsymbol{r}=\boldsymbol{r}_{s / c}-\boldsymbol{r}_{r e f}
$$

から回転系における衛星の相対位置ベクトルを求めること ができる. 時刻 $t$ のときの各要素を計算すると, 基準軌道 が円軌道の場合には

$$
\begin{aligned}
& x=-a \delta e \cos (f-\varpi)+\delta a \\
& y=2 a \delta e \sin (f-\varpi)+n a \delta t_{0}-\frac{3}{2} n\left(t-t_{0}\right) \delta a \\
& z=a \delta i \sin (f-\Omega)
\end{aligned}
$$

であり，基準軌道が楕円軌道の場合は

$$
\begin{aligned}
x= & -a \delta e \cos f+\sqrt{\frac{\mu}{p}} \delta t_{0} e \sin f \\
& +\left(\frac{r_{r e f}}{a}-\frac{3}{2} \frac{n\left(t-t_{0}\right) e \sin f}{\sqrt{1-e^{2}}}\right) \delta a \\
y= & r_{r e f}(2+e \cos f) \sin f \frac{\delta e}{1-e^{2}}+r_{r e f} \delta \omega \\
& +r_{r e f} \sqrt{\frac{\mu}{p^{3}}} \delta t_{0}(1+e \cos f)^{2} \\
& -\frac{3}{2} \frac{n\left(t-t_{0}\right) a \sqrt{1-e^{2}}}{r_{r e f}} \delta a \\
z= & r_{r e f} \delta i \sin (f-\Omega)
\end{aligned}
$$

となり, 基準衛星の近傍にある衛星の相対位置をケプラー 軌道要素の差を用いて表すことができる. 式 (32), 式 (33) を見ると, 相対位置ベクトルが真近点離角の関数 (三角関 数)となっていることが分かる.

2.2 相対位置ベクトルとその内積 (円軌道) 基準衛星 が円軌道の場合を考えると、相対運動の式である式 (32) か らも分かるように $\delta a$ の係数は時間に比例して増大寸る項 を含んでおり, $\delta a$ の存在はフォーメーションの崩壊につな
がるため

$$
\delta a=0
$$

でなければならない.今, 式 $(32)$ において

$$
\begin{aligned}
& \alpha=\delta e \cos \varpi, \quad \beta=\delta e \sin \varpi, \quad \gamma=n \delta t_{0} \\
& \delta=\delta i \cos \Omega, \quad \varepsilon=\delta i \sin \Omega
\end{aligned}
$$

となるように変数を変換すると相対位置ベクトルは

$$
\boldsymbol{r}=a\left(\begin{array}{c}
-\alpha \cos f-\beta \sin f \\
2 \alpha \sin f-2 \beta \cos f+\gamma \\
\delta \sin f-\varepsilon \cos f
\end{array}\right)
$$

とできる．これから相対位置ベクトルの内積を計算すると

$$
\frac{\boldsymbol{r}_{i} \cdot \boldsymbol{r}_{j}}{a^{2}}=p_{0}^{i j}+\sum_{k=1}^{2}\left[p_{k}^{i j} \cos k f+q_{k}^{i j} \sin k f\right]
$$

を得る.ここで, $p_{k}^{i j}, q_{k}^{i j}$ は $\chi=(\alpha, \beta, \gamma, \delta, \varepsilon)$ の関数で あり,

$$
\begin{aligned}
p_{0}^{i j} & =\frac{5}{2} \alpha_{i} \alpha_{j}+\frac{5}{2} \beta_{i} \beta_{j}+\gamma_{i} \gamma_{j}+\frac{1}{2} \delta_{i} \delta_{j}+\frac{1}{2} \varepsilon_{i} \varepsilon_{j} \\
p_{1}^{i j} & =-2\left(\beta_{i} \gamma_{j}+\beta_{j}+\gamma_{i}\right) \\
p_{2}^{i j} & =-\frac{3}{2} \alpha_{i} \alpha_{j}+\frac{3}{2} \beta_{i} \beta_{j}-\frac{1}{2} \delta_{i} \delta_{j}+\frac{1}{2} \varepsilon_{i} \varepsilon_{j} \\
q_{1}^{i j} & =2\left(\alpha_{i} \gamma_{j}+\alpha_{j}+\gamma_{i}\right) \\
q_{2}^{i j} & =-\frac{3}{2} \alpha_{i} \beta_{j}-\frac{3}{2} \alpha_{j} \beta_{i}-\frac{1}{2} \delta_{i} \varepsilon_{j}-\frac{1}{2} \delta_{j} \varepsilon_{i}
\end{aligned}
$$

である。 $\chi$ は 6 自由度から $\delta a=0$ の条件を除く 5 自由度 で構成されている. 式 $(37)$ は $f$ の最大 2 倍の周波数まで の 5 項で構成されていることに注意されたい.

2.3 相対位置ベクトルとその内積 (楕円軌道) 基準軌 道が楕円軌道である場合には，式 (33) において,

$$
\begin{aligned}
& \alpha=\frac{\delta e}{1-e^{2}}, \quad \beta=-\sqrt{\frac{\mu}{p^{3}}} \delta t_{0}, \quad \gamma=\delta \omega \\
& \delta=\delta i \cos \Omega, \quad \varepsilon=\delta i \sin \Omega
\end{aligned}
$$

のような変数変換を行うと，相対位置ベクトルは

$$
\begin{aligned}
& \boldsymbol{r}=r_{r e f} \\
& \times\left(\begin{array}{c}
-\alpha(1+e \cos f) \cos f-e \beta(1+e \cos f) \sin f \\
\alpha(2+e \cos f) \sin f-\beta(1+e \cos f)^{2}+\gamma \\
\delta \sin f-\varepsilon \cos f
\end{array}\right)
\end{aligned}
$$

となる．内積を計算すると

$$
\frac{\boldsymbol{r}_{i} \cdot \boldsymbol{r}_{j}}{r_{r e f}^{2}}=p_{0}^{i j}+\sum_{k=1}^{3}\left[p_{k}^{i j} \cos k f+q_{k}^{i j} \sin k f\right]
$$

となる.ここで 


$$
\begin{aligned}
p_{0}^{i j}= & \left(\frac{e^{2}}{2}+\frac{5}{2}\right) \alpha_{i} \alpha_{j}+\left(\frac{e^{4}}{2}+\frac{7 e^{2}}{2}+1\right) \beta_{i} \beta_{j}+\gamma_{i} \gamma_{j} \\
& -\left(\frac{e^{2}}{2}+1\right)\left(\beta_{i} \gamma_{j}+\beta_{j} \gamma_{i}\right)+\frac{1}{2} \delta_{i} \delta_{j}+\frac{1}{2} \varepsilon_{i} \varepsilon_{j} \\
p_{1}^{i j}= & \frac{5}{2} e \alpha_{i} \alpha_{j}+\left(\frac{7 e^{3}}{2}+4 e\right) \beta_{i} \beta_{j}+\gamma_{i} \gamma_{j} \\
& -2 e\left(\beta_{i} \gamma_{j}+\beta_{j}+\gamma_{i}\right) \\
p_{2}^{i j}= & \left(\frac{e^{2}}{2}-\frac{3}{2}\right) \alpha_{i} \alpha_{j}+\left(\frac{e^{4}}{2}+\frac{5 e^{2}}{2}\right) \beta_{i} \beta_{j} \\
& -\frac{1}{2} e^{2}\left(\beta_{i} \gamma_{j}+\beta_{j} \gamma_{i}\right)-\frac{1}{2} \delta_{i} \delta_{j}+\frac{1}{2} \varepsilon_{i} \varepsilon_{j} \\
p_{3}^{i j}= & -\frac{e}{2} \alpha_{i} \alpha_{j}+\frac{e^{3}}{2} \beta_{i} \beta_{j} \\
q_{1}^{i j}= & -\left(\frac{e^{2}}{2}+2\right)\left(\alpha_{i} \beta_{j}+\alpha_{j} \beta_{i}\right)+2\left(\alpha_{i} \gamma_{j}+\alpha_{j} \gamma_{i}\right) \\
q_{2}^{i j}= & -2 e\left(\alpha_{i} \beta_{j}+\alpha_{j} \beta_{i}\right)+\frac{e}{2}\left(\alpha_{i} \gamma_{j}+\alpha_{j}+\gamma_{i}\right) \\
& -\frac{1}{2}\left(\delta_{i} \varepsilon_{j}+\delta_{j} \varepsilon_{i}\right) \\
q_{3}^{i j}= & -\frac{e^{2}}{2}\left(\alpha_{i} \beta_{j}+\alpha_{j} \beta_{i}\right)
\end{aligned}
$$

である. 式 (41) を見ると円軌道の場合と異なり, $\cos$ と $\sin$ の振動項は $k=3$ まで存在し, 項の総数が 7 項となってい ることが分かる。これが楕円軌道と円軌道の違いである.

\section{3. 内積を利用した軌道設計法}

前節で求めた内積を利用した軌道設計を考える.

3.1 衛星間距離を一定に保つ軌道一般に楕円軌道上で は衛星間の相対位置関係は衛星が軌道上を移動するに従っ て大きく変化するため, 直感的には衛星間距離を一定に保 つことは難しいと考えられる。しかし, 実は式 (41) を用い ることによって軌道全周にわたって衛星間の距離をほぼ不 変とする軌道を設計することが可能である，以下では，衛 星間距離がほぼ一定に保たれる条件を解析的に示すことに する.

衛星間の距離を $D$ に保つことを考える.このとき式 (41) において $i=j$ とし，

$$
p_{0}+\sum_{k=1}^{3}\left(p_{k} \cos k f+q_{k} \sin k f\right)=\frac{D^{2}}{r_{r e f}^{2}}
$$

を満たせばよいことが分かる. 式 (2) を用いると上式の右 辺は

$$
\begin{aligned}
\frac{D^{2}}{r_{r e f}^{2}}= & \left(1+\frac{e^{2}}{2}\right) \frac{D^{2}}{p^{2}}+\frac{2 e D^{2}}{p^{2}} \cos f \\
& +\frac{e^{2} D^{2}}{2 p^{2}} \cos 2 f
\end{aligned}
$$

と変形できるから，条件は

$$
\begin{aligned}
& p_{0}=\left(1+\frac{e^{2}}{2}\right) \frac{D^{2}}{p^{2}}, \quad p_{1}=\frac{2 e D^{2}}{p^{2}}, \quad p_{2}=\frac{e^{2} D^{2}}{2 p^{2}} \\
& p_{3}=q_{1}=q_{2}=q_{3}=0
\end{aligned}
$$

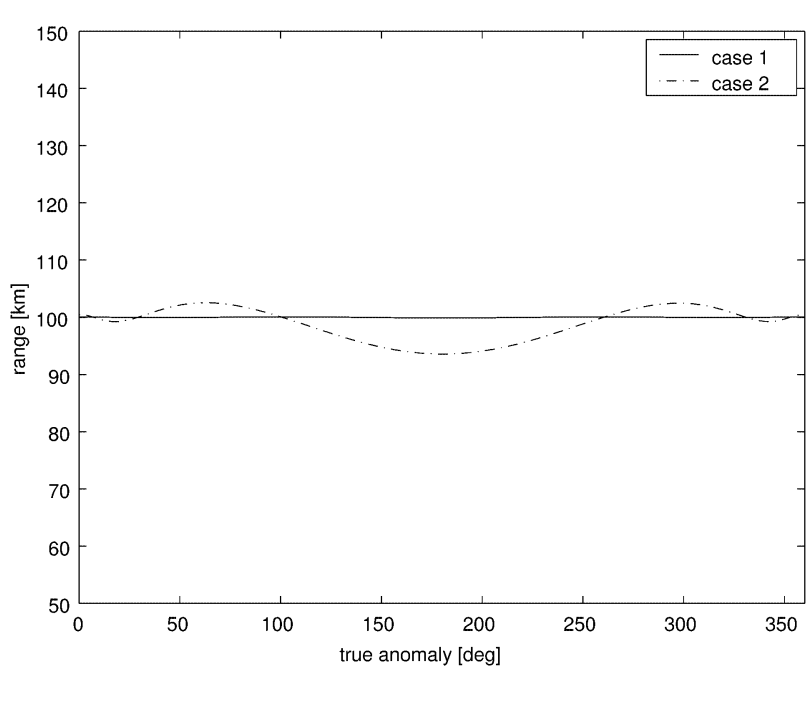

第 1 図 衛星間距離

となる. 設計すべき軌道パラメータが $(\alpha, \beta, \gamma, \delta, \varepsilon)$ の 5 つ であるのに対し条件式が 7 つであるため一般的には解は存 在しない. そこで, 高次の振動項は局地的にしか影響を及 ぼさないと仮定し， $p_{3}, q_{3}$ に関する条件式を無視すること で以下のような解が解析的に求まる.

$$
\begin{aligned}
& \alpha=0, \quad \beta= \pm \frac{2 D}{p} \frac{1}{\sqrt{7 e^{2}+8 \pm 4 \sqrt{3 e^{4}-9 e^{2}+4}}} \\
& \gamma^{2}=\left(\frac{3 e^{4}}{4}-\frac{9 e^{2}}{4}+1\right) \beta^{2}, \quad \delta^{2}=\left(-\frac{3 e^{4}}{4}+3 e^{2}\right) \beta^{2} \\
& \varepsilon=0
\end{aligned}
$$

ただし解は

$$
e<\sqrt{\frac{1}{6}(9+\sqrt{33})} \approx 0.7366
$$

の条件下においてのみ存在する. $D=100[\mathrm{~km}]$ としたとき の相対距離の履歴の例を第 1 図に示す. 具体的な軌道要素 は第 1 表に示している.

第 1 表 衛星間距離を固定する軌道の軌道要素

\begin{tabular}{lccccc}
\hline \hline & \multicolumn{2}{c}{ Case 1} & & \multicolumn{2}{c}{ Case 2 } \\
\cline { 2 - 3 } \cline { 5 - 6 } & Mother & Daughter & & Mother & Daughter \\
\hline$R_{p}[\mathrm{~km}]$ & Re+1000 & Re+1000 & & Re+1000 & Re+1000 \\
$R_{a}[\mathrm{~km}]$ & $\operatorname{Re}+5000$ & $\operatorname{Re}+5000$ & & Re+20000 & Re+20000 \\
$a[\mathrm{~km}]$ & 9378 & 9378 & & 16878 & 16878 \\
$e$ & 0.2133 & 0.2133 & & 0.5629 & 0.5629 \\
$i[\mathrm{rad}]$ & 0 & -0.0021 & & 0 & -0.0042 \\
$\Omega[\mathrm{rad}]$ & - & 0 & & - & 0 \\
$\omega[\mathrm{rad}]$ & - & 6.2779 & & - & 6.2805 \\
$\delta t_{0}[\mathrm{sec}]$ & - & -7.5153 & & - & -8.7731 \\
\hline
\end{tabular}

基準軌道の離心率 $e$ が小さいときはほぼ衛星間距離を一 定に保つことができるが, 離心率が大きくなると高次振動 
項の影響が現れてずれが生じる．ただ離心率が非常に大き くならない限り,ずれは十分小さい.

$e \rightarrow 0$ とした場合に，解は基準衛星と同一軌道上で位 相のみが異なる軌道へと収束することが分かる。これは式 (37) を用いた場合の条件

$$
p_{0}+\sum_{k=1}^{2}\left(p_{k} \cos k f+q_{k} \sin k f\right)=\frac{D^{2}}{r_{r e f}^{2}}
$$

の解の一つになっている.

本研究では解を解析的に得ることができたが，他文献で 衛星間の距離を不変とする軌道について, これとは別のア プローチで, $e \geq 0.7366$ の場合でも衛星間距離を維持する 軌道につい紹介されている2,3).

3.2 直交性に着目した軌道設計 (円軌道) $\delta a=0$ のと き，衛星の相対位置ベクトルは基準衛星を中心とし，その 周りを周回するように変化する. 今, 円軌道上を周回する 基準衛星とその近傍を運動する 2 つの衛星 (衛星 1 と衛星 2) を考える。このとき, 衛星 1 と衛星 2 の基準衛星に対す る相対位置ベクトル $\boldsymbol{r}_{1}, \boldsymbol{r}_{2}$ が直交を維持し，かつそのノ ルム $r_{1}, r_{2}$ が常に等しいという 2 つの条件

$$
\begin{aligned}
& \boldsymbol{r}_{1} \perp \boldsymbol{r}_{2} \\
& r_{1}=r_{2}
\end{aligned} \Rightarrow \boldsymbol{r}_{1} \cdot \boldsymbol{r}_{2}=0
$$

を同時に満たす軌道パラメータを見つけることができれば, その 2 つのベクトルの線形結合により任意の平面幾何形状 に対し相似形状を常に維持し続ける軌道パラメータを設計 することが可能である.

式 (49)より,

$$
p_{0}^{12}=p_{1}^{12}=\ldots=q_{2}^{12}=0
$$

式 (50)より

$$
p_{0}^{11}=p_{0}^{22}, \quad p_{1}^{11}=p_{1}^{22}, \ldots, q_{2}^{11}=q_{2}^{22}
$$

の計 10 個の条件式が発生する. これに対し軌道パラメータ は $\chi_{1}$ と $\chi_{2}$ の 10 個であるため完全に解くことができ, 解 は $\delta e_{1}$ と $\varpi_{1}$ を自由パラメータとして,

$$
\begin{aligned}
& \alpha_{1}=\delta e_{1} \cos \varpi_{1}, \quad \beta_{1}=\delta e_{1} \sin \varpi_{1}, \quad \gamma_{1}=0 \\
& \delta_{1}=\mp \sqrt{3} \delta e_{1} \sin \varpi_{1}, \quad \varepsilon_{1}= \pm \sqrt{3} \delta e_{1} \cos \varpi_{1} \\
& \alpha_{2}=-\delta e_{1} \sin \varpi_{1}, \quad \beta_{2}=\delta e_{1} \cos \varpi_{1}, \quad \gamma_{2}=0 \\
& \delta_{2}=\mp \sqrt{3} \delta e_{1} \cos \varpi_{1}, \quad \varepsilon_{2}=\mp \sqrt{3} \delta e_{1} \sin \varpi_{1}
\end{aligned}
$$

(複合同順)のように得ることができる.これによって衛星 1 と衛星 2 の相対位置ベクトルは回転座標系でそれぞれ

$$
\begin{aligned}
& \boldsymbol{r}_{1}=a \delta e_{1}\left(\begin{array}{c}
-\cos \left(f-\varpi_{1}\right) \\
2 \sin \left(f-\varpi_{1}\right) \\
\pm \sqrt{3} \cos \left(f-\varpi_{1}\right)
\end{array}\right) \\
& \boldsymbol{r}_{2}=a \delta e_{1}\left(\begin{array}{c}
-\cos \left(f-\left(\varpi_{1}+90^{\circ}\right)\right) \\
2 \sin \left(f-\left(\varpi_{1}+90^{\circ}\right)\right) \\
\pm \sqrt{3} \cos \left(f-\left(\varpi_{1}+90^{\circ}\right)\right)
\end{array}\right)
\end{aligned}
$$
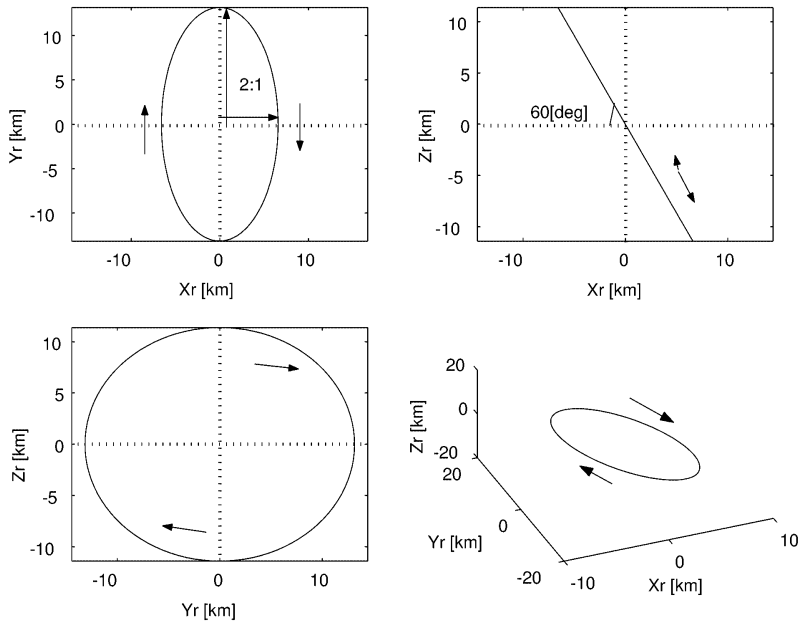

第 2 図相似な幾何形状を維持する軌道 (円軌道周り)

と表すことができる． $\boldsymbol{r}_{1}$ と $\boldsymbol{r}_{2}$ の外積をとると

$$
\boldsymbol{r}_{1} \times \boldsymbol{r}_{2}=\left(2 a \delta e_{1}\right)^{2}\left(\begin{array}{lll} 
\pm \frac{\sqrt{3}}{2} & 0 & \frac{1}{2}
\end{array}\right)^{\mathrm{T}}
$$

と一定值をとり, 衛星が回転座標系の $x y$ 平面を $y$ 軸周り に $\pm 60^{\circ}$ 回転させてできる平面上 (以後これを運動面と呼 ぶ）を運動することが分かる。運動面に投影した衛星 1 の 位置ベクトル $\boldsymbol{r}_{1}^{\prime}$ は

$$
\boldsymbol{r}_{1}^{\prime}=2 a \delta e_{1}\left(\begin{array}{c}
\cos \left(-\left(f-\left(\varpi_{1}-180^{\circ}\right)\right)\right) \\
\cos \left(-\left(f-\left(\varpi_{1}-180^{\circ}\right)\right)\right) \\
0
\end{array}\right)
$$

となる．また，衛星 2 の位置ベクトルは，式 (58)の $\varpi_{1}$ を $\varpi_{1}+90^{\circ}$ に置き換えたものに相当する. 式 (58) を見ると, 衛星 1 が運動面上で $\varpi_{1}-180^{\circ}$ を初期位相として原点を 中心に角速度 $n$ (基準軌道の平均運動) で時計回りに円運動 を行うことが分かる. 衛星 2 についても同様のことが言え る.このことから, 式 (49) と式 (50) の条件が完全に満た されており，このような軌道を用いることで相似な幾何形 状 (この場合完全に合同な幾何形状) を維持することが可能 であることが分かる。

回転座標系から見た衛星の運動の様子を第 2 図に示す. 先に述べたように, $y$ 軸の周りに $60^{\circ}$ 回転させた面上を衛 星が円運動している。このような軌道の存在は過去に確認 されておりレコード盤軌道という名前で紹介されている4).

3.3 直交性に着目した軌道設計 (楕円軌道) 前節では 円軌道近傍の相対運動において, 幾何形状が維持される軌 道配置の設計方法について論じた。本節では前節と同じ方 法を用い, 楕円軌道近傍の相対運動において, 衛星群の配 置が相似な幾何形状を維持する軌道パラメータの設計法に ついて論じる.

前節同様に楕円軌道上を周回する基準衛星とその近傍を 運動する 2 つの衛星 (衛星 1 と衛星 2) に対し, 式 (49) と 式 (50)の 2 つの条件を考える.この 2 つの条件は, 式 (41) と式 (42) を用いて 


$$
\begin{aligned}
& p_{0}^{12}=p_{1}^{12}=\ldots=q_{3}^{12}=0 \\
& p_{0}^{11}=p_{0}^{22}, \quad p_{1}^{11}=p_{1}^{22}, \ldots, q_{3}^{11}=q_{3}^{22}
\end{aligned}
$$

の計 14 の式で表される. これに対し, 変数は軌道パラメー タ $\chi_{1}$ と $\chi_{2}$ の 10 個であるため, 条件過多となり一般的に 解は求まらない. 実際にこの 14 の条件を満たす解は, 衛星 1 と衛星 2 の軌道が基準衛星の軌道と一致するもののみで あり，14の全ての条件を満たす有意な軌道パラメータは存 在しない。そこで条件を少し緩めて

$$
\boldsymbol{r}_{1} \cdot \boldsymbol{r}_{2} \approx 0, \quad r_{1} \approx r_{2}
$$

が成り立つことを条件とし，14 式の中で幾つかの成り立つ べき式を選択し，それを用いて軌道パラメータを決定する こととする. まず，最も高次の振動項である $p_{3}$ および $q_{3}$ に関する条件式の影響は局所的にしか現れないと仮定して 無視することとする. また式 $(61)$ を満たすべクトルが $1 つ$ の平面を張ることから， 2 つの自由パラメータが存在する ことを考慮し $p_{0}$ の 2 条件式も除くと, 残りの計 8 式の条 件を満たす軌道パラメータとして

$$
\begin{aligned}
\alpha_{1} & =-\sigma \cos \phi, \quad \beta_{1}=\frac{1}{e} \sigma \sin \phi \\
\gamma_{1} & =-\frac{1}{e}\left(\frac{e^{2}}{4}+1\right) \sigma \sin \phi \\
\delta_{1} & = \pm \sqrt{3-\frac{e^{2}}{4}} \sigma \sin \phi \\
\varepsilon_{1} & =\mp \sqrt{3-\frac{e^{2}}{4}} \sigma \cos \phi
\end{aligned}
$$

(衛星 2 の軌道パラメータは上式に関して $\phi \rightarrow \phi+90^{\circ}$ と したもの) を得る。ここで $\sigma, \phi$ は自由パラメータである. $\sigma$ は位置ベクトルのノルムに関するスケールファクターで あり，後に示すが $\phi$ は相対位置ベクトルのある平面上での 偏角を示している. 式 (62) のような軌道パラメータをもつ た衛星の位置ベクトルは

$$
\begin{gathered}
\frac{\boldsymbol{r}_{1}}{r_{r e f} \sigma}=\left(\begin{array}{c}
(1+e \cos f) \sin (f-\phi) \\
(2+e \cos f) \cos (f-\phi)+\frac{e}{4} \cos \phi \\
\pm \sqrt{3-\frac{e^{2}}{4}} \cos (f-\phi)
\end{array}\right) \\
\frac{\boldsymbol{r}_{2}}{r_{r e f} \sigma}=\left(\begin{array}{c}
(1+e \cos f) \cos (f-\phi) \\
-(2+e \cos f) \sin (f-\phi)-\frac{e}{4} \sin \phi \\
\pm \sqrt{3-\frac{e^{2}}{4}} \sin (f-\phi)
\end{array}\right)
\end{gathered}
$$

となる。

第 3 図と第 4 図に式 (63) と式 (64) によって得られた 2 つの相対位置ベクトルのな寸角とそれぞれのノルムの履歴 をプロットしたものを示す。条件は

- Case1: $a=2.5 R_{e}, e=0.2, \sigma=0.002, \phi=0^{\circ}$

- Case2: $a=20 R_{e}, e=0.9, \sigma=0.001, \phi=45^{\circ}$ である.このときの子衛星の軌道要素を第 2 表に示す.

図を見ると相対位置ベクトルのなす角は $90^{\circ}$ を心に振 動するが，離心率が大きくなると $90^{\circ}$ からのずれも大きく
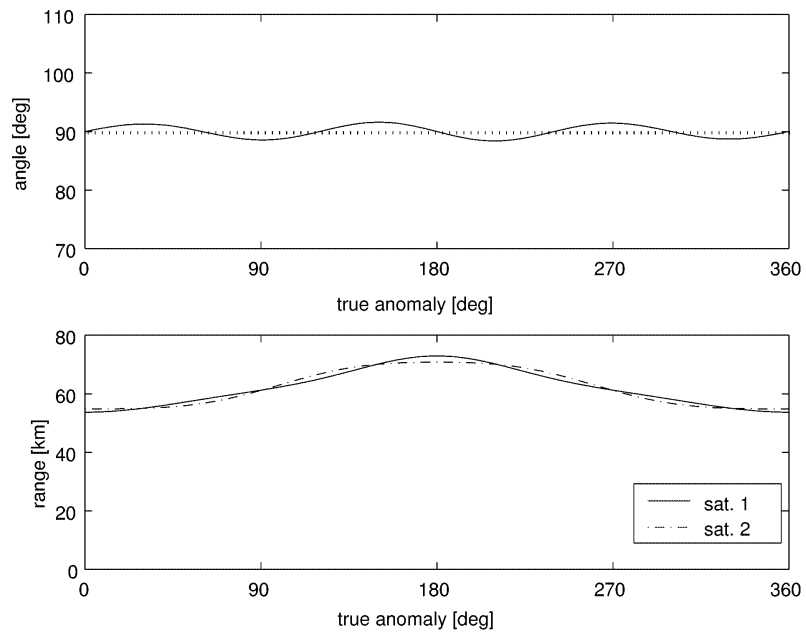

第3図＼cjkstart位置ベクトルのなす角とノルム (Case 1)
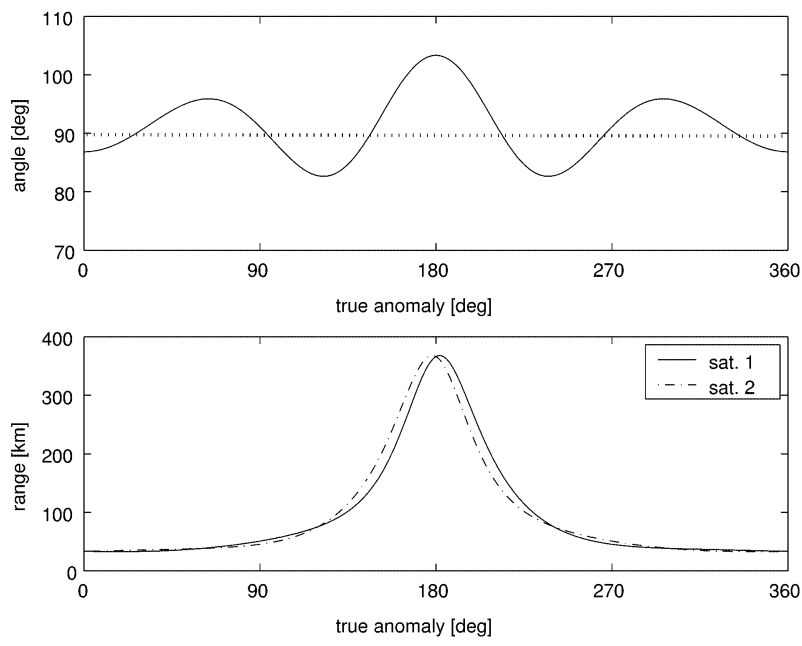

第 4 図 位置ベクトルのなす角とノルム (Case 2)

第 2 表 相似な幾何形状を維持する軌道の軌道要素

\begin{tabular}{lccccc}
\hline \hline & \multicolumn{2}{c}{ Case 1 } & & \multicolumn{2}{c}{ Case 2 } \\
\cline { 2 - 3 } \cline { 5 - 6 } & Daughter1 & Daughter2 & & Daughter1 & Daughter2 \\
\hline$\delta e$ & -0.00192 & 0 & & -0.000134 & 0.000134 \\
$\delta i[\mathrm{rad}]$ & 0.00346 & 0.00346 & & 0.00167 & 0.00167 \\
$\Omega[\mathrm{rad}]$ & 4.712 & 0 & & 5.498 & 0.785 \\
$\delta \omega[\mathrm{rad}]$ & 0 & -0.0101 & & -0.000945 & -0.000945 \\
$\delta t_{0}[\mathrm{sec}]$ & 0 & -30.0 & & -4.695 & -4.695 \\
\hline
\end{tabular}

なることが分かる。しかしながら第 4 図の場合でも遠地点 付近で $13^{\circ}$ 程度のずれが生じている他は概ね $\pm 8^{\circ}$ の範囲 内に収まっており, 式 (49)の条件をほぼ満たしていること が分かる．また相対位置ベクトルのノルムも衛星 1 と衛星 2 でほぼ等しくなっており, 式 (50)の条件も満たされてい ることが分かる。ただし円軌道の場合と異なり, 衛星 1 と 衛星 2 の相対位置ベクトルのノルムはほぼ等しくなるもの の，そのノルムが軌道一周にわたって一定值をとるわけで はない. 即ち円軌道周りのフォーメーションフライトでは, 合同な 2 次元幾何形状を維持できるが，棈円軌道周りの場 合には合同ではなく相似な 2 次元幾何形状の維持になる. 


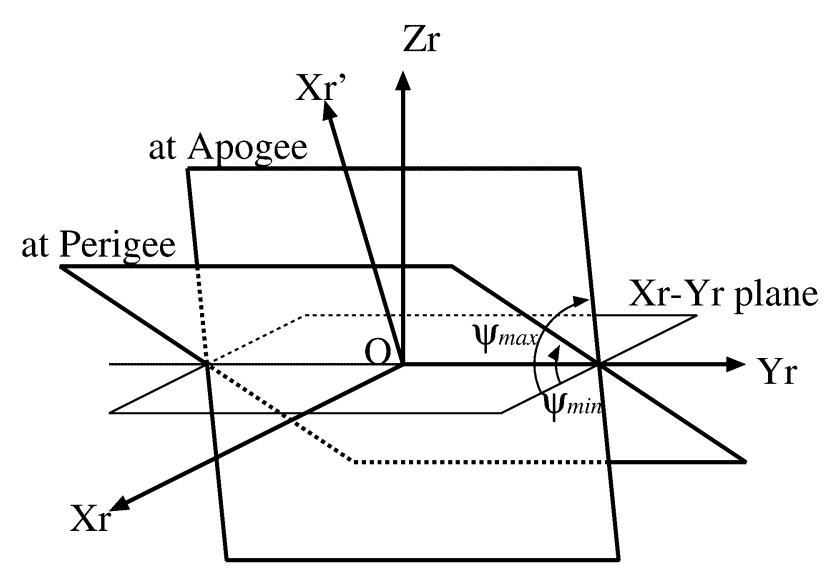

第 5 図 衛星の運動面

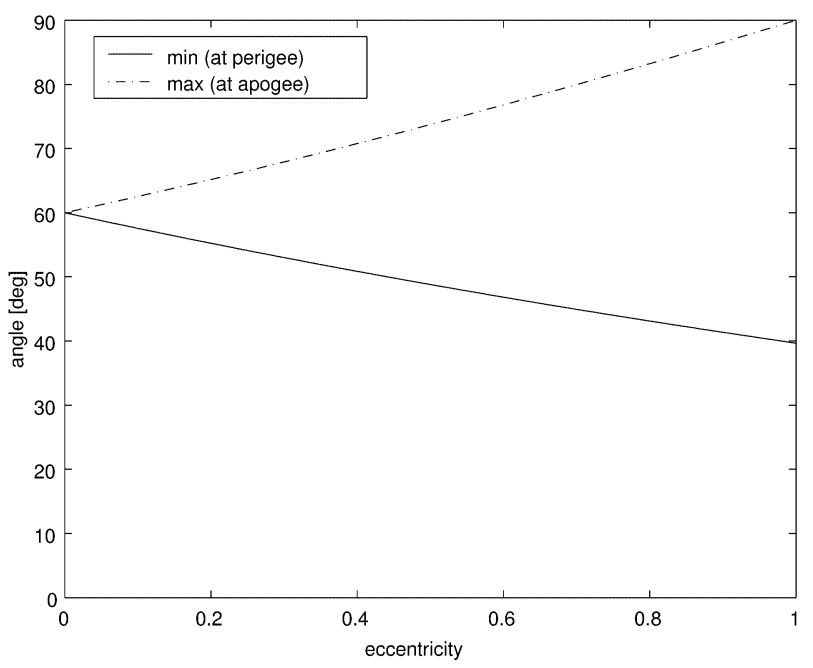

第6 図 運動面と $x y$ 平面のなす角

衛星の相対運動についてもう少し詳しく調べるため，式 (63) と式 (64) を用いて $\boldsymbol{r}_{1}$ と $\boldsymbol{r}_{2}$ の外積を計算すると

$$
\frac{\boldsymbol{r}_{1} \times \boldsymbol{r}_{2}}{\left(r_{r e f} \sigma\right)^{2}}=\left(4+\frac{3}{2} e \cos f\right)\left(\begin{array}{c}
\mp \frac{\sqrt{3-e^{2} / 4}}{2} \\
0 \\
\frac{1+e \cos f}{2}
\end{array}\right)
$$

を得る.よって衛星 1 と衛星 2 が $\sigma, \phi$ の值に関わらず回 転座標系の $x y$ 平面を $y$ 軸周りに回転させてできる平面上 $\left(x^{\prime} y\right.$ 平面, 以下これを運動面と呼ぶ $)$ で運動していること が分かる．ただし，その回転角 $\psi$ は前節のように一定では なく回転の大きさは近地点で最小值, 遠地点で最大值をと り，基準軌道の軌道周期の間に両者の間を 1 往復する (第 5 図). また, 回転角の最小值, 最大值は離心率 $e$ にのみ依 存し, 第 6 図のようになる. 最大值は $e=0$ で $60^{\circ}$ で $e$ が 大きくなるとともに増加し, $e=1$ で $90^{\circ}$ になる. また最 小值は $60^{\circ}$ から約 $40^{\circ}$ へと減少していく. 離心率 0 では回 転角は一定值 $60^{\circ}$ をとり, 前節の結果と一致する.

次に, 運動面上における衛星の位置と $\sigma, \phi$ の関係につ いて考える. 運動面に投影した衛星 1 の相対位置ベクトル

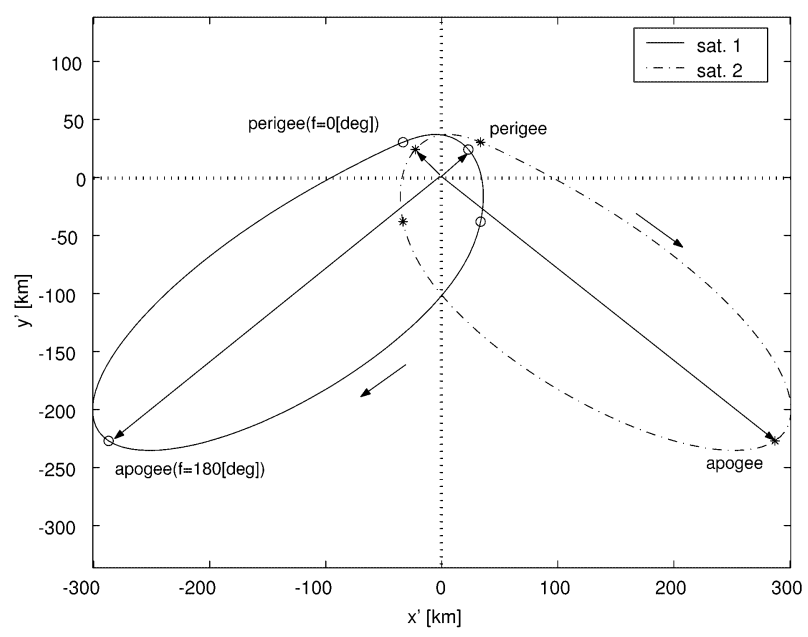

第 7 図 運動面上の相対運動

$\boldsymbol{r}_{1}^{\prime}$ は以下のように書くことができる.

$$
\frac{\boldsymbol{r}_{1}^{\prime}}{r_{r e f} \sigma}=2\left(\begin{array}{c}
\xi \cos (\phi-f) \\
\left(1+\frac{e}{2} \cos f\right) \sin (\phi-f)-\frac{e}{8} \sin \phi \\
0
\end{array}\right)
$$

ただし，

$$
\xi=\sqrt{1+\frac{e^{2}}{16}+\frac{e}{2} \cos f+\frac{e^{2}}{8} \cos 2 f}
$$

である。

式 (66) で表される相対位置ベクトルを調べると, 以下の ような性質があることが分かる。

1) 衛星は, 近地点での初期位相 $\phi$ の方向にほぼ軸対称で, 近地点で基準衛星からの距離が最小，遠地点で最大とな るような曲線上を基準軌道 1 周期の間に 1 周する.

2) 衛星が描く軌道の形状は $\phi$ によらず概ね相似であり， $\sigma$ はその軌道の大きさを決定する。

3) 衛星位置ベクトルの $x^{\prime}$ 軸からの偏角はほぼ $\phi-f$ に一 致する. 即ち衛星は基準衛星の周りを角速度 $n$ (基準軌 道の平均運動) で周回する。

第 7 図に $a=20 R_{e}, e=0.9, \sigma=0.001, \phi=45^{\circ}$ の ときの衛星 1 と衛星 2 の相対位置ベクトルを運動面に投影 したものを示す. 前述の性質を満たしつつ衛星が運動して いる様子が分かる．またこの 2)，3）の性質を利用すること で運動面上において, 任意の 2 次元幾何形状の相似性を軌 道全周にわたって維持し続けることが可能である. 近地点 $f=0^{\circ}$ において運動面上に衛星をある $\left(x^{\prime}, y^{\prime}\right)$ の位置に配 置したい場合には,

$$
\left(\begin{array}{l}
x^{\prime} \\
y^{\prime}
\end{array}\right)=2 a \sigma(1-e)\left(\begin{array}{c}
\sqrt{1+\frac{e}{2}+\frac{3 e^{2}}{16}} \cos \phi \\
\left(1+\frac{3 e}{8}\right) \sin \phi
\end{array}\right)
$$

の関係から $\sigma, \phi$ を決定し, 式 (39) と式 (63) から得られる 関係式 

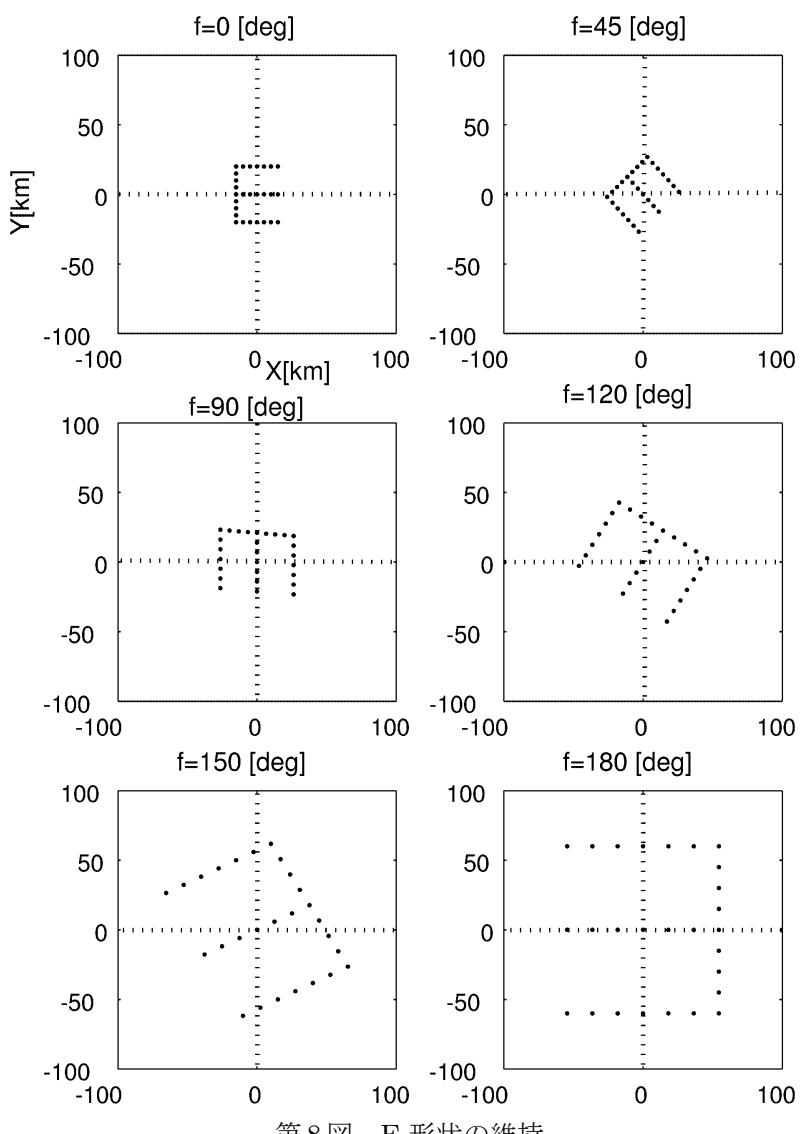

第 8 図 $\mathrm{E}$ 形状の維持

$$
\begin{aligned}
& \delta e=-\left(1-e^{2}\right) \sigma \cos \phi, \quad \delta t_{0}=-\frac{1}{e} \sqrt{\frac{p^{3}}{\mu}} \sigma \sin \phi, \\
& \delta \omega=-\frac{1}{e}\left(\frac{e^{2}}{4}+1\right) \sigma \sin \phi, \quad \delta i=\sqrt{3-\frac{e^{2}}{4}} \sigma, \\
& \Omega=\phi \mp 90^{\circ}
\end{aligned}
$$

から衛星の軌道要素を決定できる，第 8 図に，運動面上に 投影した ' $\mathrm{E}$ 'の編隊形状の維持の例を示寸. 幾何形状の大 きさは近地点付近では小さく, 遠地点付近では大きくなる が，衛星群が相似な幾何形状を全周にわたって維持してい ることが確認できる.

$$
\text { 4. ま と め }
$$

本研究では, 基準軌道の近傍で線形化した衛星の相対位 置ベクトルの内積に注目し，制御することなしに衛星間の 相対位置関係を維持することが可能な軌道の設計法につい て述べた. 結果として長楕円軌道上のフォーメーションフ ライトにおいて，近似的にではあるが

1) 相対距離を軌道全周に渡って保つ軌道

2) 2 次元的な幾何形状の相似性を軌道全周維持寸る軌道 が存在し，解を解析的に求めることができた。但し，1) と 2) を組み合わせた軌道, 即ち, 辺長が軌道全周で変化しな い正三角形等を維持する軌道等は楕円軌道上では不可能で ある。

\section{参 考 文 献}

1) 夏目耕一: 群衛星の幾何的配置を凍結する軌道設計法, 東京大学 工学系研究科修士論文, 2001

2) Tan, Z. and Bainum, P.: An Improved Strategy for Maintaining Constant Distance between Satellites in an Elliptically Orbiting Constellation, AAS/AIAA Space Flight Mechanics Meeting, 2001.

3) Bainum, P., Strong, A. and Tan, Z.: Techniques for Deploying Elliptically Orbiting Constellations in Along-Track Formation, IAC-02-A.2.05, 2002.

4) Nakasuka, S., Kawakatsu, Y., Ninomiya, T., Fujiwara, T. and Nakamura, T.: Study onthe Relative Motion and Orbit Design for Clusterd Satellites, Proceedings of 4th Workshop on Astrodynamics and Flight Mechanics, 1994, pp. 88-92. 